\title{
EDUCATION OF SOCIALITY IN SMALL COMMUNITIES
}

\author{
Audronė Dumčienė, Dalia Lapėnienė \\ Lithuanian Sports University, Kaunas, Lithuania
}

\begin{abstract}
Research background and hypothesis. Sociality in small communities leads to accrued social capital of bonding, bridging and linking. Education of community members' sociality increases bonding, bridging and linking social capital of the community.

Research aim of this study was to reveal the links between activity of community groups and community bonding, bridging and linking social capital.

Research methods. The subjects filled in the questionnaire based on the research of F. J. Elgar et al. (2011). The sociality was associated with community social capital, namely its components of bonding social capital, bridging social capital and linking social capital. The subjects were asked to evaluate the items using Likert type 5 point scale.

The participants were divided into two groups: engaged in community activities ( 240 people, among them $35 \%$ males and 65\% females, mean age 48.52 years) and not engaged in activities (262 people, $62.6 \%$ females and $37.4 \%$ males, mean age 46.97 years).

Research results. The estimates of both groups on bonding social capital scale were not statistically significant $(\mathrm{p}>0.05)$. Statistically significant differences were found assessing the bridging social capital $(\mathrm{p}<0.05 ; \mathrm{t}=4.56)$, and linking social capital $(\mathrm{p}<0.05 ; \mathrm{t}=3.17)$ in both groups. Checking the differences of opinions between both groups of men - men and women - women showed statistically significant differences only for women's bridging social capital $(\mathrm{p}<0.05 ; \mathrm{t}=88.19)$ and linking social capital $(\mathrm{p}<0.05 ; \mathrm{t}=4.01)$.

Discussion and conclusions. The data confirmed the hypothesis that bridging and linking social capital was related to community engagement. The engaged participants indicated higher levels of bridging and linking social capital.
\end{abstract}

Keywords: community, sociality, bonding social capital, bridging social capital, linking social capital.

\section{INTRODUCTION}

$\mathrm{C}$ ommunity fragmentation and lack of engagement is supported by various studies, so researchers from different fields are encouraged to explore the process of community development. Recent discussions in the literature link community development and community resource mobilization. According to D. V. Rainey et al. (2004), there are three forms of capital: human capital, social capital and financial capital. It helps small communities to compete successfully in the global economy, but all three kinds of resources should be mobilized and continuously developed through active engagement in social networks.
Communities' social networks, defined as social capital, are of primary value.

People who are engaged in social networks are active participants in the local economy, so they actively create financial capital and material goods. Social networking also creates an added value because the engagement in community participation is linked to such goods as commitment, satisfaction, collaboration, support and approval, consulting, recommendations, and acknowledgment. Community participation is the source of such social and emotional goods as care, 
safety, recognition, shared values, commitment, empathy, etc. (Robison, Ritchie, 2010).

Community engagement is closely related to social capital because it facilitates cooperation and optimal utilization of resources inherent in social networks (Putnam, 1993, 2000; Coleman, 2003). Social capital can be defined and measured in different ways, but people's ability to act collectively and to achieve common goals are two common features in different social capital definitions (Skačkauskienè, Bytaute, 2012).

Probably the most influential social capital concept was introduced by R. Putnam (2000) as well as S. Szreter and M. Woolcock (2004), who distinguished three social capital dimensions: bonding social capital, bridging social capital and linking social capital. The bonding social capital describes trust based social relationships between individuals of similar interest, which are often connected by blood or similar relations. Usually bonding social capital is formed on the basis of social identity: people trust and cooperate with others because they identify themselves as the members of a particular group. The bridging social capital includes confidence in different persons, who usually do not belong to the same family, social group, nationality or race. The bridging social capital is formed when a person starts relations with new colleagues, new neighbours, organizations and staff representatives, and keeps relationship of trust, hoping that those people would never ignore or reject. Linking social capital involve relationship of trust between different people in the society, who have different power and influence. Linking social capital includes public confidence in law enforcement institutions. The society, which has a lot of linking social capital, supports government representatives and fosters goodwill based on democratic relationships.

The concept of modern social capital measurement is based on three traditions: measurement of confidence as individuals' attitude, measurement of participation in social groups and institutions and measurement of confidence in police and law enforcement institutions (Righi, 2013). In the first case, measuring the confidence levels in the community, people bonding social capital can be measured. It is a valuable indicator of how much individuals tend to cooperate with others while creating social welfare. In the second case the bridging social capital can measured. It reveals how individuals tend to join groups, clubs, associations, seeking to solve problems and achieve common goals. In the third case linking social capital is measured. It reveals how much confidence people give to the law and political institutions.

Community engagement and active participation allows the use of social capital in three ways. It is possible, that active engagement in community organizations is related to the trust of other people, different groups of people, as well as law enforcement authorities.

The aim of this study was to reveal the links between community engagement and social capital dimensions.

The hypothesis of the study was to reveal that community engagement predicted the level of social capital of the community.

\section{RESEARCH METHODS}

Research participants. The sample of the study was composed of the residents of 12 townships from rural area. According to the study aims, the sample was divided into two groups. The first group included persons engaged in various community groups, the second one was not engaged in any community group activity. The first group was composed of 84 men (35\% of the group), and 156 women ( $65 \%$ of the group). The mean age of the first group subjects was 48.52 years. The respondents were selected by the recommendations of a representative of the municipality. The second group was composed of 262 subjects: 98 men (37.4\% of the group), and 64 women $(62.4 \%$ of the group). The mean age of the second group subjects was 46.49 years. Each participant of the second group was asked about their engagement in community activities.

Measures. The subjects filled in the questionnaire based on the research of F. J. Elgar et al. (2011). For social capital assessment in the community, the questionnaire including 15 items was used. After a short introduction of the study aims, the subjects were asked to evaluate how much they could trust their family members, relatives, neighbours, friends and acquaintances. The subjects were asked to evaluate the level of social capital using Likert type five point scale. These questions were interpreted as the scale of bonding 
social capital. In the second question the subjects were asked to indicate how much they could trust the person they met for the first time, the person of different religion, different nationality, the person working illegally, and the person not buying a ticket in the bus. These questions were interpreted as the scale of bridging social capital. In the third question the subjects were asked to indicate how much they could trust the local municipality representative, police, court, parliament and government. These questions were interpreted as the scale of linking social capital. The subjects were also asked to indicate their age, gender and social status (employed or unemployed, retired).

Statistical analysis. In order to estimate the reliability of the scales Cronbach's alpha coefficients were calculated. The values were sufficient for the study (i. e. 0.72 for bonding social capital; 0.70 for bridging social capital; 0.65 for linking social capital).

The difference between the groups was considered to be reliable with Student's $t$ test statistical significance set at $p<0.05$. Before the test of means, equality of dispersion was checked up using Fisher F-test. The data were expressed as means \pm standard deviations.

Binary logistic regression was used in order to estimate predictive relations between community engagement and social capital dimensions. The engagement in community activities was considered as dependent variable. Participants were divided into two groups: engaged (0) and not engaged (1). The estimates of linking, bridging, and bonding social capital were considered as independent variables. In order to fulfil the requirements of a binary regression, these estimates were converted into binary variables: the social capital scale mean was lower than $2.49(0)$ and the social capital scale mean was higher than 2.50 (1).
These calculations were performed using SPSS Statistics 17.0.

\section{RESEARCH RESULTS}

The main results of the study are presented in Table 1.

The mean groups of the bonding social capital scale did not differ significantly in two groups. This means that family members, relatives, neighbours, friends and acquaintances were the subjects of mutual trust in both cases.

The results obtained during the study (Table 1) showed that statistically significant differences between the groups were estimated in two cases - in the case of bridging social capital $(\mathrm{p}<0.05 ; \mathrm{t}=4.56)$ and in the case of linking social capital $(\mathrm{p}<0.05 ; \mathrm{t}=3.17)$. The data showed that actively engaged people displayed more confidence in various social groups and law enforcement authorities

In order to evaluate predictive value of community engagement to social capital, binary logistic regression analysis was made. It was found that the level of engagement into community actions determined social capital accumulation $(\mathrm{p}<0.05)$. The results of binary logistic regression indicated the relation between the community engagement and social capital. The estimated relations might be explained theoretically. Bridging and linking social capital is developed when people participate in the activities of various social groups and institutions. Mutual trust in the community is the main premise for this participation.

The data allowed drawing the conclusion that community engagement was an important predictor of bridging and linking social capital. The next

\begin{tabular}{|l|c|c|c|c|}
\hline \multirow{2}{*}{ Social capital } & Engaged (n= 240) & Disengaged (n= 262) & \multirow{2}{*}{ t-test $^{1 / 2}$} & p \\
\cline { 2 - 4 } & $\mathbf{M} \pm \mathbf{S D}$ & $\mathbf{M} \pm \mathbf{S D}$ & & \\
\hline Bonding capital & $3.48 \pm 0.93$ & $3.12 \pm 1.31$ & $\mathrm{t}=0.496$ & $\mathrm{p}>0.05$ \\
\hline Bridging capital & $2.81 \pm 0.65$ & $2.12 \pm 0.79$ & $\mathrm{t}=4.56$ & $\mathrm{p}<0.05$ \\
\hline Linking capital & $2.51 \pm 0.55$ & $1.29 \pm 0.22$ & $\mathrm{t}=3.17$ & $\mathrm{p}<0.05$ \\
\hline
\end{tabular}

Table 1. Values of scores of three forms of social capital

Note. Values are expressed as mean \pm SD. Significant differences were set by independent samples Student's t-test among groups: 1 - engaged, 2 - disengaged. 


\begin{tabular}{|c|c|c|c|c|c|c|}
\hline \multirow{4}{*}{$\begin{array}{l}\text { Table } 2 \text {. Values of the acti- } \\
\text { vity estimates of men and } \\
\text { women participating and } \\
\text { non-participating in com- } \\
\text { munity groups }\end{array}$} & \multirow{2}{*}{\multicolumn{2}{|c|}{$\begin{array}{l}\text { Social capital } \\
\text { and gender }\end{array}$}} & \multicolumn{2}{|c|}{ Engaged } & \multicolumn{2}{|c|}{ Disengaged } \\
\hline & & & $\mathbf{M} \pm \mathbf{S T}$ & t-test $t^{1 / 2}$ and $p$ & $\mathbf{M} \pm \mathbf{S T}$ & t-test $t^{1 / 2}$ and $p$ \\
\hline & \multirow{2}{*}{ Bonding } & Men & $3.20 \pm 1.04$ & \multirow{2}{*}{$\begin{array}{l}\mathrm{t}=1.00 \\
\mathrm{p}>0.05\end{array}$} & $2.57 \pm 1.49$ & \multirow{2}{*}{$\begin{array}{l}\mathrm{t}=1.47 \\
\mathrm{p}>0.05\end{array}$} \\
\hline & & Women & $3.76 \pm 0.83$ & & $3.72 \pm 1.21$ & \\
\hline \multirow{4}{*}{$\begin{array}{l}\text { Note. Values are expressed } \\
\text { as mean } \pm \text { SD. Significant } \\
\text { differences were set by in- } \\
\text { dependent samples Student's } \\
\text { t-test among groups: } 1 \text { - } \\
\text { men, } 2 \text { - women. }\end{array}$} & \multirow{2}{*}{ Bridging } & Men & $2.0 \pm 1.02$ & \multirow{2}{*}{$\begin{array}{l}\mathrm{t}=4.83 \\
\mathrm{p}<0.05\end{array}$} & $2.33 \pm 1.09$ & \multirow{2}{*}{$\begin{array}{l}\mathrm{t}=2.90 \\
\mathrm{p}<0.05\end{array}$} \\
\hline & & Women & $4.04 \pm 0.35$ & & $1.17 \pm 0.08$ & \\
\hline & \multirow{2}{*}{ Linking } & Men & $1.93 \pm 0.99$ & \multirow{2}{*}{$\begin{array}{l}\mathrm{t}=1.06 \\
\mathrm{p}>0.05\end{array}$} & $1.29 \pm 0.34$ & \multirow{2}{*}{$\begin{array}{l}\mathrm{t}=0.02 \\
\mathrm{p}>0.05\end{array}$} \\
\hline & & Women & $2.53 \pm 0.90$ & & $1.29 \pm 0.15$ & \\
\hline
\end{tabular}

important question was to indicate the influence of demographical variables for this relationship.

In order to indicate the main differences in two groups, the means were calculated and statistically significant differences of the means were explored using Student's $t$ test for independent samples. The gender emerged as the single statistically significant demographical variable. Data on the gender differences of opinion are presented in Table 2.

Bridging social capital was the only variable when statistically significant mean differences between men and women were estimated $(\mathrm{p}<0.05 ; \mathrm{t}=4.83)$. Nevertheless, the data suggested that women might be more likely to engage in community activities. Bridging social capital is defined as trust in various social groups and tendency to engage in their activities. It is possible that women have more sociality and relationship orientation, which increases possibility of community engagement.

Checking the scale mean differences between the two groups of men - men and women - women showed statistically significant differences only for the group of women's bridging social capital $(\mathrm{p}<0.05 ; \mathrm{t}=88.19)$, and linking social capital $(\mathrm{p}<0.05 ; \mathrm{t}=4.01)$.

\section{DISCUSSION}

R. Putnam (2000) and later S. Szreter and M. Woolcock (2004) distinguished three dimensions of social capital: bonding social capital, bridging social capital and linking social capital. The study disclosed the expedience of this distinction. Social capital refers to the resources in social networks. Trust in the community is the primary source of social capital (Putnam, 2000). It is considered that trust is the precondition for community engagement, but the study shows that this relation is more complicated than it seems. The data confirmed the hypothesis that bridging and linking social capital are related to community engagement. This means that people in small rural communities, who come together and organize the same cultural or educational activities, demonstrate more bridging and linking social capital. The question is why they demonstrate that and why there is no similar relationship between community engagement and bonding social capital. It is important to note that both groups tend to indicate higher levels of bonding social capital in comparison with bridging social capital or linking social capital. On the other hand, the mean of bonding social capital scale is 3.48 for engaged participants and 3.12 for disengaged participants. The participants demonstrated moderate levels of trust in people who were relatively significant for them, but confidence in the reference group was not related to the community engagement.

H. Meulemann (2008) describes three types of associations existing in the community: interest based associations, problem based associations and religious associations, which are both interest (value) based and problem based. It would be fruitful 
to develop the research exploring the relationship between the dimensions of social capital and engagement in different types of associations in the community.

Theresults of the studies proved the relationships between social capital and individual/family characteristics, as well as the psychological wellbeing of adolescents. Indicates that the association between social capital and psychological wellbeing for adolescents differs in a specific family in regard to individual and family characteristics. Thus, social capital is important for maintaining the psychological well-being of adolescents.

So, it can be assumed that social capital might influence the well-being of adults, but this assumption needs more research to confirm it.

\section{CONCLUSION AND PERSPECTIVES}

The hypothesis of the study was confirmed. Sociality of active community members increases the social capital, which is prerequisite for community well-being. To strengthen sociality of the active members in the community, it is appropriate to include more members of the community seeking various community activities.

Social capital might be the source of social and emotional well-being only when community engagement exists. Women tend to indicate the higher level of bridging social capital in comparison to men.

Two major limitations should be considered in the future studies. The first one is related to sampling procedures. Random sampling and larger samples would give more reliable data and more valuable generalizations. The second one is related to important variables related to social capital. It was assumed that social capital was the source of social and emotional well-being, such as individual well-being, shared values, support, approval, etc. It would be useful to investigate the relations of social capital and selected social and emotional wellbeing of the engaged and disengaged community members.

\section{REFERENCES}

Coleman, J. A. (2003). Religious social capital. Its nature, social location, and limits. In C.E. Smidt (Ed.), Religion as Social Capital: Producing the Common Good. Baylor University press.

Elgar, F. J., Davis, Ch. G., Wohl, M. J. et al. (2011). Social capital, health and life satisfaction in 50 countries. Health \& Place, 17, 1044-1053.

Meulemann, H. (2008). Is altruism more effective where it is required more? Collectivity-orientation and involvement in interest, issue, and religious associations. In H. Meulemann (Ed.), Social Capital in Europe: Similarity of Countries and Diversity of People. MultiLevel Analyses of the European Social Survey 2002. Brill.

Putnam, R. (2000). Bowling Alone: the Collapse and Revival of American Community. New York: Simon and Schuster.

Putnam, R. (1993). Making Democracy Work: Civic Traditions in Modern Italy. Princeton. Princeton University Press.
Rainey, D. V., Robinson, K. L., Allen, I., Christy, R. D. (2004). Essential forms of capital for achieving sustainable community development. In. R. D. Christy (Ed.), Achieving Sustainable Communities in a Global Economy: Alternative Private Strategies and Public Policies. World Scientific.

Righi, A. (2013). Measuring social capital: Official statistics initiatives in Italy. Procedia. Social and Behavioral Sciences, 72, 4-22.

Robinson, L. J., Ritchie, B. K. (2010). Relationship Economics: The Social Capital Paradigm and Its Application to Business, Politics and Other Transactions. Gower.

Skačkauskienė, I., Bytaute, S. (2012). Socialinio kapitalo apibrèžties ir matavimo problema. Verslas: teorija ir praktika, 13 (3), 208-216.

Szreter, S., Woolcock, M. (2004). Health by association? Social capital, social theory, and the political economy of public health. International Journal of Epidemiology, $33,650-667$. 


\title{
BENDRUOMENIŠKUMO UGDYMASIS MAŽOSE BENDRUOMENĖSE
}

\author{
Audronė Dumčienė, Dalia Lapėnienė \\ Lithuanian Sports University, Kaunas, Lithuania
}

\section{SANTRAUKA}

Tyrimo pagrindimas ir hipotezė. Bendruomeniškumas mažose bendruomenėse lemia kaupiamą ịsipareigojimo, suartėjimo ir susiejimo socialini kapitalą. Bendruomenès nariams ugdantis bendruomeniškumą didèja bendruomenės isipareigojimo, suartejimo ir susiejimo socialinis kapitalas.

Tikslas - atskleisti bendruomenès grupių veiklos ir bendruomenès issipareigojimo, suartejjimo ir susiejimo socialiniu kapitalu sąsajas.

Metodai. Tiriant buvo naudojamas klausimynas, sukurtas naudojant F. J Elgar ir kt. (2011) pagrindines mintis. Bendruomeniškumas tyrimo metu siejamas su socialiniu kapitalu, tiksliau jo sudètinèmis dalimis - bendruomenès isipareigojimo, suartejimo ir susiejimo socialiniu kapitalu.

Respondentai buvo prašomi penkių balų Likert skalèje įvertinti klausimyne pateiktus teiginius. Buvo išskirtos dvi respondentų grupès: dalyvaujantys bendruomenės veikloje ( 240 žmonių, tarp jų $35 \%$ vyrų ir $65 \%$ moterų; amžiaus vidurkis 48,52 metų) ir nedalyvaujantys (262 žmonès, 62,6\% moterų ir 37,4\%vyrų; amžiaus vidurkis 46,97 metų).

Rezultatai. Abiejų grupių nuomonės vertinant ịsipareigojimo socialiniu kapitalu požymius esmingai nesiskyrė $(p>0,05)$. Statistiškai reikšmingai nuomonès skyrèsi vertinant suartejjimą $(p<0,05 ; t=4,56)$ ir susiejimą socialiniu kapitalu $(\mathrm{p}<0,05 ; \mathrm{t}=3,17)$. Tikrinant nuomonių skirtumus tarp abiejų grupiu poromis vyrai-vyrai ir moterysmoterys nustatytas statistiškai reikšmingas suartejimo $(\mathrm{p}<0,05 ; \mathrm{t}=88,19)$ ir susiejimo socialiniu kapitalu $(\mathrm{p}<0,05$; $\mathrm{t}=4,01)$ požymių moterų vertinimo skirtumas.

Galima teigti, kad mažų miestelių žmonès, menkiau išsiugdę bendruomeniškumo bruožus, mažiau pasitiki ne artimais žmonėmis bei savivaldos ir valstybès institucijomis nei asmenys, veikiantys įvairiose bendruomenės grupèse.

Aptarimas ir išvados. Veikla bendruomenès grupèse palankiai ugdo bendruomeniškumą, taigi ir socialinio kapitalo stiprinima, kuris yra prielaida bendruomenès narių gerovei. Suartejjimo socialiniu kapitalu požymis būdingesnis moterims nei vyrams.

Raktažodžiai: bendruomenè, bendruomeniškumas, issipareigojimo socialinis kapitalas, suartèjimo socialinis kapitalas, susiejimo socialinis kapitalas.

Gauta 2013 m. spalio $31 \mathrm{~d}$.

Received on October 31, 2013 